\title{
NOTÍCIAS D’ALÉM-MAR: o tema do sufrágio e da cidadania das mulheres na imprensa brasileira oitocentista.
}

\author{
Priscila Salvaia*
}

RESUMO: Reconhecido por um discurso jornalístico liberal e progressista, na segunda metade do século XIX, o periódico fluminense $O$ Globo abordava com certa frequência o tema da inserção das mulheres na sociedade. Tal noticiário, na maioria das vezes, era proveniente de realidades estrangeiras, concebidas pelos editores do jornal como exemplos de modernidade. Neste artigo, nossa principal preocupação foi a de decifrar as formas de apropriação e transmissão dessas ideias aos leitores e leitoras brasileiros de então.

PALAVRAS-CHAVE: Imprensa; Cidadania; Mulheres.

\section{News from the overaseas: the theme of suffrage and citizenship of women in the brazilian press during the nineteenth century.}

\begin{abstract}
Known for a liberal and progressive journalistic discourse, in the second half of the $19^{\text {th }}$ century, the periodical $O$ Globo, published in the city of Rio de Janeiro, somewhat frequently approaches the theme of the inclusion of women in society. Such newspaper, most of the times, was derived from foreign realities, perceived by its editors as examples of modernity. In this paper, our main concern was to untangle the forms of appropriation and transmission of those ideas to the Brazilian readers - both men and women - at that time.
\end{abstract}

KEYWORDS: Press; Citizenship; Women.

\section{Noticias d'allende los mares: el tema del sufragio y de la ciudadanía de las mujeres en la prensa brasileña ochocentista.}

RESUMEN: Reconocido por un discurso periodístico liberal y progressista, en la segunda mitad del siglo XIX el periódico fluminense O Globo abordaba a menudo el tema de la inserción de las mujeres en la sociedad. Tal noticiario, en la mayoría de las veces, provenía de realidades extranjeras concebidas por los editores del periódico como ejemplos de modernidad. En este artículo, nuestra principal preocupación ha sido la de descifrar las formas de apropiación y transmisión de esas ideas a los lectores y lectoras brasileños de entonces.

PALABRAS CLAVE: Prensa; Ciudadanía; Mujeres.

\footnotetext{
*Doutoranda em Teoria e História Literária no Instituto de Estudos da Linguagem da Universidade Estadual de Campinas (IEL/UNICAMP). Email: priscila_salvaia@ hotmail.com.
} 


\section{Introdução:}

O presente artigo faz parte de uma trajetória de pesquisa dedicada ao tema da atuação do escritor Machado de Assis na imprensa brasileira oitocentista ${ }^{1}$, e ainda que o literato não seja o foco deste texto, faz-se imprescindível revelar algumas das motivações que contribuíram diretamente para a concepção de toda a argumentação que será exposta a seguir.

Recorrendo ao aporte metodológico da área de História Social da Cultura ${ }^{2}$, sempre buscamos "historicizar" a produção do citado autor, inserindo-o na realidade social de seu próprio tempo. Dessa maneira, investigamos quais as possíveis relações da publicação do folhetim Helena (1876) em meio a um importante jornal da época, $O$ Globo, reconhecido por seu discurso progressista ${ }^{3}$. E diante da premissa de uma protagonista pautada por signos de autonomia feminina frente às opressões do patriarcalismo, nos debruçamos sobre as páginas do periódico fluminense para tentar compreender se esta Helena afinava-se ao ideário apregoado pela folha. Ou seja, partimos com a intenção de apreender os sentidos associados às experiências dos leitores e leitoras da época, que acompanharam o romance em seu suporte original de publicação.

Dessa forma, começamos a nos aproximar da temática deste artigo: a imprensa e as possibilidades de experiência de leitura de sujeitos históricos que partilhavam daquilo que chamaremos de uma "poética cultural" referenciada nas ideias que circulavam na época. $\mathrm{O}$ conceito, já utilizado por Ivan Teixeira (TEIXEIRA, 2010, p.28-32), diz respeito a um tipo de análise que, frente a um texto literário, procura investigar os mecanismos segundo os quais as várias instâncias da cultura se articulam para tornar possível o seu sentido. Assim, ao inferir tais significados à prática da leitura, deparamo-nos com uma atividade profundamente social ${ }^{4}$.

Tomando a imprensa como fonte de pesquisa, buscamos reconstituir alguns aspectos deste horizonte cultural/social que, do nosso ponto de vista, permeou a percepção desses leitore(a)s, que também chamaremos de interlocutore(a)s. Enfim, o mesmo Globo que trouxe a lume a vívida (e quase insolente) Helena de Machado de Assis, também apresentou ao seu público tantas outras mulheres, não-ficcionais, e quase sempre estrangeiras que se opunham às opressões sofridas em sociedades que lhes negavam autonomia e cidadania. E é sobre elas que falaremos nesse artigo. $\mathrm{Na}$ verdade, falaremos sobre elas a partir do discurso editorial do Globo, e tentando nos aproximar das possíveis reações do público brasileiro exposto às demandas de movimentos que, na segunda metade do século XIX, começavam a reivindicar o feminismo ao redor do mundo. 


\section{Sobre o jornal $O$ Globo: perfil editorial.}

Propriedade de uma Associação Anônima, O Globo surge em 1874 como um periódico devotado a um público interessado em temas ligados à economia e finanças, dessa maneira, os principais interlocutores seriam identificados entre os grandes proprietários. Após sucessivas crises, o perfil editorial do jornal modifica-se, e passa a existir uma preocupação maior em atender outros tantos setores da sociedade, como, por exemplo, os trabalhadores urbanos e indivíduos comuns, interessados em temas menos sisudos e mais cotidianos à cidade do Rio de Janeiro. Nesse momento (entre 1875 e 1876), além dos temas, os preços também se tornariam mais acessíveis e, os exemplares vendidos nas ruas, chegam a custar somente 60 réis cada ${ }^{5}$. De todo modo, algumas constantes devem ser sublinhadas.

Tendo como referências as principais potências estrangeiras da época: Estados Unidos, Inglaterra e França, a folha caracterizava-se por um discurso econômico liberal, e ainda que a leitura detida do jornal revele os conflitos e incoerências desse mesmo discurso, faz-se necessário enfatizar que a reinvindicação pelos signos de modernidade, era o principal argumento evocado nos editoriais do jornal. Ademais, há de se considerar a presença do editor-chefe Quintino Bocaiúva por trás da publicação, uma figura essencial para os primórdios do nosso jornalismo, e reconhecido articulador do movimento republicano no Brasil. Por fim, e talvez pelas armadilhas impostas pelo ideário progressista apregoado, o tema da inserção social das mulheres surgia recorrentemente, ainda que elas não fossem referenciadas como público-alvo do periódico. Também vale citar os folhetins, presentes desde o início da circulação do jornal.

Em relação ao noticiário estrangeiro, alguns detalhes necessitam ser esmiuçados. À primeira vista, tal noticiário se conjugava à tônica de um jornal dedicado aos proprietários e comerciantes, interessados, sobretudo, nas oportunidades em mercados internacionais promissores. Contudo, a gama de assuntos era bastante variada, e tudo o que se passava no cenário político francês, no cotidiano de países industrializados como a Inglaterra, ou ainda, na progressista sociedade norte-americana, entre outras nações, parecia mobilizar os editores da folha que selecionavam tais notícias em jornais oriundos desses países, ou publicavam aquilo que era enviado por correspondentes radicados no exterior. Por vezes, tais novidades eram sobriamente transmitidas, tendo-se em vista uma postura editorial que primava por uma suposta imparcialidade jornalística. Mas, na maioria dos casos, eram evidentes as intromissões dos redatores nos conteúdos publicados. Não eram raros os correspondentes 
internacionais que acrescentavam comentários tendenciosos às notícias colhidas no exterior. Bem como eram recorrentes as publicações de notícias "recortadas" em jornais estrangeiros que seguiam replicadas junto de "pequenos apêndices valorativos" delineados em "traços grossos" pelos redatores do Globo. Nesse sentido, parecia haver uma intenção deliberada de preparar as formas de recepção dessas novidades entre o público-leitor do jornal.

Muito embora não prevíssemos somente leitores e leitoras obedientes, parece interessante ressaltar os riscos empreendidos por tais jornalistas que, como num jogo de "mostra e esconde", abordavam ideários considerados extremamente progressistas, mas, de forma explícita ou subentendida, julgavam e advertiam sobre as incongruências e impossibilidades de importação do que era exposto. Por isso, atentar nos critérios que balizavam as escolhas dos editores se configura numa premissa muito importante para a compreensão das estratégias e dos embates envolvidos na apropriação, introjeção e transmissão de realidades tão diversas.

\section{Mas, até parece que as mulheres fazem as leis.}

Como ponto de partida, e a fim de explicar os sentidos do subtítulo escolhido, recorremos a uma alusão constante nas páginas do periódico: o caso das mulheres norteamericanas. Os Estados Unidos se configuravam como uma referência importantíssima aos editores do jornal, que viam o país como exemplo de ex-colônia que despontava através da ideologia liberal e que, por isso, deveria ser compreendido como modelo a ser seguido por outros países que haviam se livrado de tutelas europeias e buscavam emergir em contextos periféricos. Os avanços sociais também entravam para o mote dos admiráveis progressos alcançados nas prósperas terras do norte; por exemplo, a campanha pela abolição da escravatura parecia uma inspiração ao caso brasileiro, além disso, a visibilidade das mulheres e as lutas por direitos civis também se convertiam em pautas para discussões acaloradas. $\mathrm{O}$ texto abaixo, possivelmente enviado por um correspondente, traz algumas observações de um sujeito estrangeiro claramente surpreendido com as possibilidades desfrutadas pelas estadunidenses de então:

As mulheres nos Estados Unidos

A primeira impressão dos estrangeiros, ao pisarem em solo americano, é um sentimento de estranheza ao ver andar sós pelas ruas tanto as meninas como as mulheres, olhando para toda a gente e sorrindo-se com uma liberdade que à princípio é qualificada de descaramento. 
No entanto, é a cousa mais natural; desde que têm uso de razão estão acostumadas a fazê-lo, e por certo honra-as muito que essa ilimitada franqueza não produza resultados desagradáveis.

A lei naqueles países é tão galante que qualquer adivinharia a secreta mão feminina em a redação de seus princípios severos, que se são guardas fiéis dos costumes que por muito livres se vêm frequentemente ameaçados, também entregam os homens atados de pés e mãos e sem defesa ante o juramento sempre acreditado de aventureiras que gozam de todos os privilégios do seu sexo.

$\mathrm{O}$ juramento da mulher vale em primeiro lugar o de dous homens reunidos, e a estes compete apresentar testemunhas para destruírem a acusação, porque só as mulheres são acreditadas sob palavra de honra, e geralmente as que recorrem aos tribunais são tão generosas que se oferecem a sofrer elas sós o peso de sua desonra, mediante uma indenização avantajada que sem remédio tem a pagar o infeliz que obrou imprudentemente.

(Grifo nosso. "As mulheres nos Estados Unidos". O Globo, Rio de Janeiro, 7 de junho de 1876, p.2).

As mulheres norte-americanas saiam às ruas. Mais que isso. Mesmo as mulheres norte-americanas "de bem" saiam às ruas, e sim, deveriam ser respeitadas também por isso. Tendo-se em vista a valorização dos signos em torno da honra feminina, o testemunho das mulheres valeria mais que o masculino, o que, de acordo com a insinuação do nosso redator, movimentaria um escuso comércio de álibis entre homens desesperados por absolvição e "aventureiras" acreditadas aos olhos da justiça. Aliás, a lei naquele país seria tão "galante" e tolerante para com as mulheres, que não seria um despropósito supor mãos femininas empenhadas em sua redação! Pilhérias à parte, de fato, quando comparado ao caso brasileiro, o incurso das mulheres americanas à vida pública e as mobilizações em torno de seus direitos civis se deram de forma bastante articulada nos Estados Unidos desde muito cedo.

Reproduzido nas páginas do Globo, o texto a seguir foi originalmente publicado na imprensa francesa, e tratava das recomendações dos norte-americanos aos visitantes do Velho Continente que se dirigiam à América. Em 1876 a imprensa americana se ocupava especialmente dos festejos pelo Centenário da Independência dos Estados Unidos, e o texto em questão tratava dos preparativos da Exposição que seria realizada na Filadélfia para comemorar a referida data. Como eram esperados muitos visitantes, principalmente europeus, os americanos se incumbiam de alertar que, nos EUA, as mulheres desfrutavam de condições mais livres:

[...] Será conveniente que os visitantes estrangeiros que afluírem à nossa cidade no próximo verão fiquem sabendo que as condições sociais não são sempre equivalentes às do antigo continente. As mulheres americanas têm, e desde muito tempo, o costume de andar sós pelas ruas, quando vão a negócio ou a passeio. Que os visitantes do continente admitam como axioma que as senhoras da Filadélfia, Nova Iorque ou Cincinnati, não têm necessidade de escolta ou de proteção de um pajem ou de um amigo quando querem sair. 
[...] a moda começou talvez durante a guerra, quando as mulheres tinham necessidade de ser elas próprias portadoras de suas cartas ao correio e a pagar suas contas; comprar extras nos caminhos, e ir ao encontro dos trens de ferro que chegavam à meia-noite, na esperança de encontrar seus parentes. Parece-nos, porém, que devemos algumas explicações aos nossos hóspedes. Em Filadélfia que já se torna uma cidade poliglota, duas senhoras que passavam à tarde por uma rua tranquila, foram cumprimentadas de modo muito familiar por um estrangeiro.

Muito incomodadas com isto, pediram a um gentleman que passava o favor de tirálas daquela tão embaraçosa situação.

O gentleman, interpelando bruscamente o ofensor, perguntou-lhe como se atrevia ele a faltar assim ao respeito a essas ladies.

Ladies, meu Deus! replicou ele. Não são de certo, senhor. As ladies não percorrem sozinhas as ruas à semelhante hora.

Uma palavra de aviso será suficiente aos visitantes de bom senso.

Talvez seja preciso uma lição mais severa para fazer compreender que neste país as ladies saem quando bem lhes apraz, apoiando-se apenas no respeito leal dos americanos, não menos que em sua dignidade e boa educação.

("Centenário Americano: Exposição de Philadelphia [Do Courrier des Estats-Unis]." O Globo, Rio de Janeiro, 19 de julho de 1876, p.1.

São muitos os fatores que explicam os caminhos trilhados pelas mulheres estadunidenses até a inserção na esfera pública. Na perspectiva de uma historiografia mais tradicional, são comuns as leituras baseadas nos conflitos ocorridos durante a Guerra Civil (1861-1865), que terminariam por revelar um cotidiano de mulheres solitárias, que não tinham outra opção além de procurar meios próprios de sobrevivência. Talvez daí os referidos sentimentos de tolerância para com essas viúvas e órfãs que, forçosamente sós, faziam-se notáveis no cotidiano das ruas. Utilizando-se de argumentos que também confluem para a questão da Guerra, são frequentes as interpretações que associam a abolição da escravidão ao despertar de uma chamada "consciência feminista". Nesse caso, são consideradas as interrelações dos grupos abolicionistas formados por mulheres que, envolvidas nas reinvindicações pela liberdade dos negros, acabavam tomando consciência do próprio estado de submissão ${ }^{6}$.

Em estudos mais recentes, algumas dessas perspectivas são criticamente revisitadas. Por exemplo, de acordo com Michelle Newman (NEWMAN, 1999), as abolicionistas das décadas de 1840 e 1850 enfatizavam as semelhanças entre a opressão patriarcal e a condição de sujeição dos negros escravizados. Porém, após a Guerra Civil, tal discurso seria rearticulado a partir de novos termos e, ao invés de argumentar com base em uma "vitimização" semelhante à dos escravos, tais militantes passariam a apregoar uma pretensa superioridade racial e cultural em relação aos egressos da escravidão. Assim, a partir da reformulação de conceitos evolucionistas, as mulheres brancas oriundas de meios mais abastados se colocariam como "força civilizatória" na inserção social de grupos 
marginalizados. Portanto, na perspectiva de Newman, as intersecções entre o abolicionismo e o feminismo não seriam explicáveis somente a partir de interpretações baseadas em empatias sôfregas.

A partir de uma abordagem igualmente revisionista, Nancy Isenberg (ISENBERG, 1998) também procura questionar alguns dos aspectos envolvidos nessa relação perpetuada pela historiografia. Em sua análise, a autora propõe um amplo exame do movimento feminista norte-americano, abrangendo-o às mais diversas esferas da representatividade social. Nesse sentido, o ideário protestante e as associações femininas surgidas no interior das igrejas são analisados como meios essenciais ao exercício de uma cidadania criticamente concebida. Nessas agremiações se dariam os primeiros indícios em torno de experiências políticas participativas, claramente atentas aos desígnios da sociedade civil. Entre as diversas causas que aproximavam tais mulheres, frequentemente se notava a questão da abolição da escravidão, no entanto, diversas outras demandas as mobilizavam. Sem dúvidas, a questão do sufrágio deve ser relacionada a essa ampla gama de debates. E se retomarmos as páginas do Globo, perceberemos que essas novidades não eram desconhecidas de seu público:

Direitos políticos das mulheres nos Estados Unidos

No dia 25 do mês passado foi apresentada no senado dos Estados Unidos, pelo Sr. Sargent da Califórnia, uma petição assinada pelas Sras. Mathilde Joslyn Gage, Ellen C. Sargent, Lucrecia Mott, Elisabeth Cady Stanton, Suzana B. Anthony, E.D.E.N. Southworth, Sara J. Spencer, Izabel B. Hooker e outras muitas, na qual ponderam que a corte suprema dos Estados Unidos, a resolver os pleitos de Spencer contra a junta registradora, e de West Webster contra os juízes de eleições, confirmou uma decisão anterior da corte suprema relativa à que pela primeira seção da emenda 14 da constituição, as mulheres foram consideradas cidadãs e, portanto, tendo direito de votar. As subscritoras de tal documento apelam para o congresso, a fim de que se tome providências para tornar-se efetivo o cumprimento da referida emenda.

Em nossa opinião, as ditas senhoras, prestariam mais serviços ao país e à humanidade, educando bem os seus filhos e cuidando na boa ordem e governo de suas casas, do que pretendendo envolver-se nas lutas de partidos e em contendas políticas, que são infelizmente uma das calamidades que pesam sobre os povos na época atual.

("Direitos políticos das mulheres nos Estados Unidos". O Globo, Rio de Janeiro, $1^{\circ}$ de maio de 1876, p.2).

Se recorrermos à bibliografia sobre o tema do sufrágio universal nos Estados Unidos, torna-se possível esclarecer as diversas informações elencadas no texto. Sabemos que os nomes citados se referem às reconhecidas líderes envolvidas na história do movimento feminista nos EUA, entretanto, não estamos em busca de grandes personalidades compreendidas em suas excepcionalidades. Isso porque pensamos que essas notáveis mulheres, também devem ser lidas a partir de suas inter-relações com as oprimidas que, supostamente, compõe a regra (VARIKAS \& RIOT-SARCEY, 1998). Isto posto, talvez seja 
mais interessante mantermos o foco nas possibilidades de recepção desse noticiário entre os leitores do periódico.

Desse modo, independente do entendimento pormenorizado do texto, o público-leitor da folha era colocado diante de um debate sólido, que tocava nas reinvindicações das mulheres estadunidenses por cidadania e especificamente pelo sufrágio. Portanto, um novo cenário de mobilizações sociais era apresentado. Entretanto, ao final do texto, e provavelmente com o intuito de remediar qualquer interpretação precipitada do conteúdo exposto, seguia o ponto de vista acachapante defendido pelo jornal: "Em nossa opinião, as ditas senhoras, prestariam mais serviços ao país e à humanidade, educando bem os seus filhos e cuidando na boa ordem e governo de suas casas, do que pretendendo envolver-se nas lutas de partidos e em contendas políticas...". De maneira abrupta, a notícia era "traduzida" aos leitores do Globo nos termos da realidade vivenciada pelas mulheres brasileiras que, em sua grande parte, estavam - e talvez devessem permanecer - restritas aos espaços domésticos.

Pois bem. Não seria demasiado enfatizar que na domesticidade também existiriam conflitos arbitrados a partir dos choques em torno dos papéis reservados aos gêneros. Contudo, e ao que parece, a notícia tratava das demandas por representatividade das mulheres junto ao poder público, possibilidade esta categoricamente negada no discurso editorial da folha. De qualquer forma, e conforme já afirmamos, nos parece interessante o jogo de "mostra e esconde" proposto pelos editores do jornal. Se por um lado, tais mobilizações seriam destacadas em suas propostas por direitos políticos, por outro, parecia existir uma necessidade de desqualificação das informações veiculadas. A impressão depreendida é a de que haveria uma atmosfera receosa entre os editores sobre os efeitos que o noticiário poderia causar, daí a necessidade de interferência tão explícita. Porém, é difícil afirmar se corações e mentes poderiam ser instigados, ou frustrados, com uma nota tão breve - embora não isolada. E cogitando-se a mais trivial das hipóteses, entre os leitores mais atentos do periódico, um paradoxo à conjuntura brasileira era claramente estabelecido.

\section{Entre o paradoxo, a aproximação e o medo: as inconvenientes liberdades pleiteadas pelas mulheres.}

Partindo da constatação de uma realidade majoritariamente patriarcal, os caminhos e descaminhos abordados pelo Globo, demonstravam as contradições inescapáveis que envolviam a compreensão e a apropriação dos ideários que mobilizavam tais mulheres no exterior. E mesmo que a prerrogativa da rejeição norteasse parte significativa desse noticiário, 
ainda assim, é importante enfatizar que os editores não optaram por omitir-se diante de tal debate. Resguardando-se em um discurso editorial moderno, quiçá vanguardista, o periódico se colocava a serviço de um público interessado nas novidades que movimentavam os grandes centros internacionais, por isso, parecia impossível escapar ao evidente tema das lutas das mulheres por liberdade, especialmente no caso dos Estados Unidos.

Em outro texto relativamente semelhante ao anterior, os avanços feministas nos EUA seriam novamente referenciados, porém, desta vez as considerações traçadas eram um pouco mais paliativas. $\mathrm{O}$ artigo fazia parte de uma série sobre instrução pública e, talvez, por isso mesmo, terminava por estabelecer algumas conjecturas a respeito das possibilidades de influência desse ideário emancipacionista no Brasil:

[...] O papel da mulher na sociedade está naturalmente traçado: é serem mães de família e inspirarem os sentimentos nobres e grandes a seus filhos e às crianças, cuja direção lhes é confiada.

Não aceitamos nem as ideias de uma certa escola americana, que prega a emancipação da mulher sob um ponto de vista especial, nem as teorias do grande Stuart Mill, que queria pudessem elas tomar parte até nas questões políticas, tendo o direito de votar e serem eleitas.

Por ora, enquanto a sociedade não atingir a esse ideal de perfeição sonhado por certa escola filosófica, achamos que não pode haver mais nobre papel para a mulher, que o de educar seus filhos, e inspirar-lhes sentimentos puros.

Para a mulher poder, porém, satisfazer aquele importante papel, é preciso seja ela educada e instruída.

É justamente essa a maior dificuldade que encontramos no Brasil.

Queremos a liberdade do ensino, como queremos todas as outras; alguns inconvenientes que disso resultarem são incontestavelmente sobrepujados pelas vantagens obtidas.

("Reformas necessárias na Instrução Pública". O Globo, Rio de Janeiro, 16 de março de 1876, p.1).

De início, através de um discurso já bastante conhecido, eram enfatizados os papéis reservados às mulheres: esposa e mãe. Logo em seguida, são desprezadas as ideias libertárias que inspiravam as americanas, porém, tal negação não se daria de maneira vazia ou ignorante, uma vez que nosso redator deixava claro que não aceitava as influências das "ideias de certa escola americana que pregava a emancipação da mulher", nem das teorias do grande Stuart Mill. Apesar das generalizações, o texto foi concebido por alguém que acompanhava de perto as transformações levadas a cabo no exterior. E se naquele momento ainda não seria possível apropriar-se de tal ideário, num futuro esperançoso de mulheres educadas e instruídas, conjecturava-se que as brasileiras pudessem se aproximar das mesmas autonomias conquistadas ou reivindicadas pelo movimento feminista estadunidense. É claro que nesse novo cenário alguns "inconvenientes" poderiam surgir... Eis o ônus de se desejar uma sociedade tão moderna! Mas, tais incômodos certamente seriam sanados pelas vantagens 
vislumbradas. Portanto, ainda que de maneira parcimoniosa, o autor acabava flertando com as aspirações por liberdade feminina.

$\mathrm{Na}$ verdade, parece confortável, ou pouco crítico, o argumento de que a sociedade ideal não havia sido atingida; ou de que experiências femininas mais autônomas somente encontrariam respaldo num futuro indeterminado, quase idílico, onde todas as mulheres teriam acesso a uma educação que, de fato, fosse esclarecedora. Nesse caso, tudo se resumiria a mero exercício retórico? Pensamos que não. Primeiramente chama a atenção o fato de que, numa série de artigos que tratava da educação das meninas brasileiras, viesse à tona o "contra exemplo" de uma escola americana que pregava a emancipação das mulheres; ou ainda, que se esboçassem algumas críticas a Stuart Mill. Ou seja, mesmo as "negações" do redator eram conscientemente direcionadas, o que demonstraria certo envolvimento intelectual em tal debate.

Levando-se em conta a inserção do texto na série sobre educação, é possível cogitar que o autor teria a intenção de discutir modelos pedagógicos a serem adotados no ensino público feminino, talvez daí uma oposição subentendida aos modelos de ensino associados aos princípios protestantes que poderiam resultar numa atmosfera mais propícia ao desenvolvimento do espírito crítico em relação às tradições culturais que sublinhavam o estatuto da subordinação da mulher ${ }^{7}$. Segundo Jane Soares de Almeida (ALMEIDA, 2002, p.185-207), no Brasil dos anos de 1870, as escolas públicas eram quase inexistentes e, na falta dessas escolas, os protestantes encontraram ambiente propício para implantar instituições calcadas nos seus próprios métodos pedagógicos e orientadas pelos seus princípios religiosos.

No amálgama de todas as "inconvenientes liberdades" pleiteadas pelo movimento feminista estadunidense, novamente era destacada a questão do sufrágio que, desta vez, seria associada à figura de John Stuart Mill. A alusão ao intelectual era feita de maneira breve, sem muitos detalhes explicativos e, de fato, eram dispensáveis grandes esclarecimentos. Conforme demonstraremos, os leitores do Globo estavam a par da referência citada.

Como já afirmado, além das novidades vindas da América, também eram publicadas diversas notícias oriundas de vários outros países considerados estratégicos no cenário da época. Dentre eles, outra nação frequentemente destacada nos editoriais do Globo era a Inglaterra, sempre compreendida como exemplo a ser seguido, principalmente pela notável ascensão econômica baseada em uma tecnologia industrial arrojada para a época. Em meio a tantos progressos, volta e meia surgiam algumas notas a respeito das articulações do movimento feminista inglês por direitos políticos, tema em evidência na Inglaterra durante a década de 1870, quando foram propostos projetos de lei que tratavam de tais demandas. 
De Londres, as notícias eram enviadas por um correspondente que sempre assinava seus textos com o pseudônimo de "H.J.". Geralmente, o anônimo jornalista brindava o público com um resumo das manchetes dos jornais ingleses, assim como informava a respeito dos debates que ocorriam na Câmara dos Comuns. No exemplo a seguir, "H.J." abordava algumas das discussões suscitadas pelos trâmites de um bill em votação no ano de 1876, e que tratava da concessão do direito eleitoral às mulheres. Ao longo do texto, a atuação de Stuart Mill era referenciada. Tais evidências parecem sugerir alguma familiaridade dos leitores do Globo com a atuação desse intelectual inglês, reconhecidamente comprometido com os desígnios por igualdade feminina:

[...] Concluirei hoje a tarefa que me impus escrevendo estas mal traçadas linhas, dando-vos uma notícia que, conquanto não se refira positivamente à vossa pátria, liga-se a toda parte do mundo - existe a criatura que nos é mais cara - a mulher.

De novo, como vereis dos jornais, apresentou-se à câmara dos comuns um bill concedendo o direito eleitoral às mulheres, que foi rejeitado por vários membros do ministérios liberal, ao passo que o Sr. Disraeli e outros conservadores votaram com a minoria.

Houve dois discursos notáveis, sendo um do Sr. J. Bright, e outro do Sr. Fawcett sustentando o bill.

Levantou-se, porém, depois o irmão mais velho do Sr. Bright, que declarou que outrora apoiara a proposição de Stuart Mill, mas que hoje a considera inoportuna e perigosa, tanto para os costumes públicos como para o interesse do país.

Outro orador disse que a ingerência do belo sexo em política seria desastrosa. [...] Os jornais de mais voga ocuparam-se também desta questão, que parece ter sofrido son dernier coup no ano da graça de 1876 e no reinado de Victória, rainha da Inglaterra e imperatriz da Índia. [...]

E fico por aqui hoje.

Londres.

H.J.

(H.J. [pseudônimo não identificado]. "O Brazil na Inglaterra". O Globo, Rio de Janeiro, 4 de junho de 1876, p.1).

Apesar do desfecho negativo, o texto tratava de um debate tenso, e institucionalizado pelas mobilizações feministas. Entre discursos sentenciosos, indecisões e retrocessos, era apresentada uma arena de disputas onde diversos interesses eram colocados em jogo. $\mathrm{O}$ tema do sufrágio feminino era “inoportuno", “desastroso”, evidentemente “perigoso”. É possível afirmar que a rejeição e os temores de alguns setores políticos em relação a tal questão, seriam explicáveis através da constatação de que o movimento feminista inglês, em seu cerne, sempre esteve ligado ao maciço operariado feminino que atuava em um dos principais alicerces econômicos da Inglaterra: a indústria têxtil (SCOTT \& TILLY, 1989).

No cotidiano exaustivo das fábricas formavam-se identidades coletivas e associações de classe que, conjuntamente fortalecidas, davam voz às mulheres dentro e fora do ambiente fabril. Na Inglaterra, à semelhança do que aconteceu nos Estados Unidos, os reclamos das 
mulheres pelo sufrágio se davam a partir da legitimação ao exercício do trabalho. Ou seja, nos termos de um feroz liberalismo econômico, se as mulheres podiam trabalhar e contribuir economicamente, logo, elas deveriam ser consideradas cidadãs plenas, com direito a voto. Portanto, em ambos os casos, os argumentos econômicos sucediam os argumentos pautados pelo Direito Natural (KÄPPELI, 1991). E, tendo-se em vista o potencial inflamável dessas agremiações classistas, os receios daqueles que desejavam a manutenção do status quo não seriam infundados.

A inserção das mulheres no mundo profissional ajustou-se às necessidades de uma lógica econômica exploratória, que tomava a mão de obra feminina como artigo barato. Ainda assim, a nova situação transformava profundamente as solidariedades tradicionais, alterava as relações entre homens e mulheres e penetrava pouco a pouco nas mentalidades, impondo a imagem da mulher na esfera pública. Enfim, os tênues limites entre a exploração, a autonomia e os desígnios em torno da feminilidade ressoavam com alguma frequência entre os leitores da folha.

Ainda no bojo das discussões sobre o sufrágio feminino na Inglaterra, através do jornal seria possível conferir outros vários textos que acompanhavam tal questão. Mas, pelos diversos sentidos que podem ser depreendidos, selecionamos o seguinte excerto de um longo artigo publicado por um correspondente que, situado na França, acompanhava atentamente os debates que ocorriam na Inglaterra:

[...] Em França os conservadores estremecem logo que se lhes fala de liberdade de imprensa, de associação, de reunião. Qualquer melhoramento, por mais insignificante que seja, lhes parece uma coisa monstruosa; não querem até ouvir falar em semelhante coisa, e tapam os ouvidos.

Os ingleses são mais práticos, porque não matam nem adiam qualquer discussão. Ainda muito recentemente, discutiu-se no parlamento inglês uma questão que se tivesse sido suscitada em França, teria acarretado a seus iniciadores uma série de desgostos. Refiro-me aos direitos políticos das mulheres. Se houvesse um deputado assaz temerário que ousasse suscitar semelhante questão na tribuna, ficaria esmagado sob o peso dos motejos e das injúrias, No parlamento inglês foi ela extensivamente debatida. Uma minoria imponente de 152 votos pronunciou-se em favor da emancipação política das mulheres, e dentre esses 152 votos, conta-se o do chefe dos conservadores da Inglaterra, do primeiro ministro do gabinete atual, do próprio Sr. Disraeli, enfim!

Estou longe, pelo que me diz respeito pessoalmente, de ser partidário do que se convencionou chamar emancipação das mulheres, e certamente não votaria do mesmo modo porque o fez o Sr. Disraeli, mas o fato que acabo de recordar e que se passou ainda não há dez dias, mostra que na Inglaterra não se receia tratar em pleno dia, pública e ostensivamente, as mais delicadas questões do problema social, ao passo que em França receia-se puerilmente a discussão destes assuntos que constantemente são adiados, como se não chagasse infalivelmente uma hora fatal em que o adiamento não é mais possível.

("Republica Francesa (carta do nosso correspondente) - Paris, 8 de maio de 1876." O Globo, Rio de Janeiro, 3 de junho de 1876, p.1 e 2). 
No famoso ensaio As mulheres ou os silêncios da história, de Michelle Perrot, há um longo capítulo intitulado "As mulheres e a cidadania na França: história de uma exclusão" (PERROT, 2005, p.327-341). Nele a autora analisa as dificuldades de acesso à cidadania feminina na França desde os inícios da Revolução Francesa (1789), quando se definiu uma cidadania civil, porém não política para as mulheres, passando pelos retrocessos com a imposição do Código Civil em 1804, que considerava as mulheres "cidadãs passivas", e atentando-se ainda na Revolução de 1848 e no Segundo Império (1852-1870), quando avanços significativos seriam alcançados. Contudo, as francesas somente poderiam votar em 1945.

A análise crítica apresentada por Perrot converge com as considerações traçadas pelo correspondente do Globo e, se pensarmos no contexto inglês vitoriano (1837-1901) de notáveis progressos econômicos e sociais, torna-se possível compreender algumas das diferenciações enfatizadas pelo jornalista. No entanto, talvez seja infrutífero deter-se num exame comparativo de tais conjunturas neste momento, isso porque, nos interessa muito mais esclarecer outros aspectos que constituem a argumentação sustentada no artigo, inserindo-o ainda na trama complexa das várias outras notícias veiculadas no jornal e que também tratavam da situação das mulheres francesas no século XIX.

Se analisarmos a trajetória argumentativa proposta pelo redator do Globo, pode ser que alguns detalhes soem um pouco confusos. Inicialmente os conservadores franceses são tripudiados pela inércia e indisposição em discutir temas importantes, que visavam melhoramentos essenciais à sociedade da época, como no exemplo das reformas que tratavam da liberdade de imprensa. Por outro lado, os ingleses seriam mais "práticos" e progressistas, pois, em pleno dia, se dispunham a enfrentar temas que causavam desgostos aos espíritos mais retrógrados, como era o caso dos debates ocorridos pela emancipação política das mulheres. Por fim, e numa espécie de "faça o que digo, mas não faça o que faço", o anônimo jornalista fazia questão de enfatizar que, pessoalmente, não era a favor da emancipação feminina, porém, reafirmava sua admiração pelas instâncias inglesas sensíveis a tais reivindicações sociais. $\mathrm{E}$ nas últimas e fatídicas linhas, o trecho alertava para a impossibilidade de adiar-se tal debate também nas instituições políticas francesas.

As crescentes demandas feministas que assolavam diversos países europeus também encontravam respaldo na França de então. Por sinal, ao longo da década de 1870, as páginas do Globo foram constantemente impressas com textos que tratavam da questão do divórcio, tema muito em voga naquele momento. 
Em 1876 o deputado Alfred Naquet propunha um projeto de lei que defendia o restabelecimento do divórcio na França. Em suas cláusulas, o projeto previa o direito ao divórcio em casos de incompatibilidade de temperamentos; por consentimento mútuo; por adultério cometido por qualquer uma das partes; além de casos excepcionais que poderiam ser considerados pela jurisprudência. Pouco antes, em 1875, Naquet já havia publicado um programa no qual defendia o divórcio, assim como o direito das mulheres gerirem seus bens e de serem reconhecidas do ponto de vista $\mathrm{civil}^{8}$. Ou seja, as imbricações entre o divórcio e os direitos das mulheres eram evidentemente indissolúveis. No Código Civil ${ }^{9}$ era previsto apenas o "divórcio culposo" em casos excepcionais que envolvessem adultério; sevícias; injúrias graves; e condenação a pena infamante. O texto abaixo, publicado no Globo, traz alguns dados estarrecedores sobre os casos de separação conjugal ocorridos na França entre os anos de 1840 e 1863. Acompanhemos:

\begin{abstract}
Divórcio
O Dr. Drouet, de Paris, acaba de publicar um livro, no qual pede às câmaras francesas o restabelecimento do divórcio, fundando-se em grandes considerações civis, morais e políticas. Sem que seja nosso propósito discutir a importância da petição, reproduziremos alguns dados estatísticos dos contidos no livro de que nos ocupamos, e que dão uma triste ideia dos modernos costumes em certos povos que pretendem ser os primeiros em todos os progressos.

No período de 23 anos, isto é, desde 1840 a 1863, instauraram-se em França 38.492 processos de divórcio, e destes, 3.069 a instâncias do marido, e 32.763 a instâncias da mulher.

Da estatística que fez Mr. Drouet resulta que os maridos na sua maior parte foram levados aos tribunais por suas mulheres, por causa da brutalidade de seu caráter e por maus tratamentos que lhes davam, e que quase a totalidade dos divórcios pedidos pelos esposos tiveram por fundamento a falta de fidelidade de suas esposas. ("Divórcio". O Globo, Rio de Janeiro, 19 de junho de 1876, p. 2).
\end{abstract}

Reconhecendo a imprecisão dos números, consideremos a porcentagem aproximada de que mais de 85\% dos processos de divórcio instaurados na França entre 1840 e 1863, foram impetrados por mulheres. Ainda de acordo com o texto, entre os principais motivos alegados, destacavam-se os casos de maus tratos cometidos por maridos autoritários. Muito provavelmente as queixas se relacionavam à chamada "supremacia marital" que submetia as mulheres casadas ao estado de dependência e proteção do cônjuge. Nessa situação, prevista pelo direito, a mulher casada era praticamente desconsiderada em sua individualidade civil e, assim como uma menor de idade, era subjugada à autoridade patriarcal. Daí os constantes casos de abuso de poder, violência e humilhação.

No entanto, e conforme exposto, eram numerosas as mulheres que não se calavam e procuravam os meios legais para dissolver uniões destrutivas e infelizes. E, se pensarmos no casamento como uma instituição política, para além de uma relação de âmbito privado, torna- 
se possível depreender a capacidade das mulheres promoverem transformações em todos esses domínios.

No lado oposto, e em número bem mais reduzido, também seriam citados os maridos que procuravam o divórcio de esposas acusadas de infidelidade. Para compreender um pouco melhor a questão, talvez sejam necessários alguns breves esclarecimentos. Conforme afirmado, o adultério era aceito como causa de separação em tribunal, no entanto, existiam muitas diferenças no tratamento de homens e mulheres no que diz respeito à comprovação da traição. Assim, na França, até 1884 o adultério da mulher era um ato espontâneo, que podia ser provado por qualquer meio (frequentemente pelo roubo de cartas). Em contrapartida, o delito do marido, só seria punível se a concubina fosse mantida sob o teto conjugal, além disso, somente o flagrante e a apresentação de provas concretas poderiam constatar a traição masculina. No segundo caso, eram consideradas as correspondências que por ventura caíssem nas mãos das esposas, todavia, o testemunho masculino era especialmente levado em consideração na confirmação ou descrédito desse tipo de prova.

Vulneráveis em sua honra, as mulheres casadas sofriam com uma legislação condescendente com o patriarcalismo. E apesar dos debates suscitados em 1876, somente em 1884 a lei do divórcio seria aprovada na França. Até então, conforme exposto, a permissão ao divórcio se restringia aos casos considerados "culposos" pelo Código Civil. Porém, como proceder em casos não previstos por essa legislação? Por exemplo, o que poderia ser feito em situações de desamor, tédio, desinteresse, ou diante dos mais diversos motivos que poderiam minar uma relação? Teoricamente, nada além de conformar-se. Contudo, as práticas cotidianas e os usos da lei ofereciam respostas bem mais complexas. O texto abaixo traz a notícia de uma mulher que "aparentemente sem motivos" desejava dar fim ao próprio casamento. Para tanto, ela falsificaria cartas do marido com intuito de criar provas de uma suposta traição. Ou seja, a artimanha forjava um caso previsto na lei. A maestria do golpe vale a leitura:

\footnotetext{
Malícia mulheril

Não se fala atualmente, diz o Constitucional de Paris, nas salas de uma das principais cidades de Borgonha, senão de um processo de separação dos mais curiosos, no qual se dá um fato bastante raro, se por ventura já alguma vez aconteceu, em um gênero de processo em que os esposos dão largas habitualmente a toda a sua malícia.

A esposa, bonita como os amores, nova, catita e cheia de gentileza, quer a todo pano a sua liberdade como se vai ver. Não tinha queixas sérias a alegar contra seu marido. Este, sem estar de todo satisfeito com sua mulher, não quer, contudo, abandoná-la, por causa do escândalo e para interesse dos filhos.

Sabem o que a tal senhora imaginou? Exercitou-se em escrever cartas anônimas, e tornou-se tão mestra que deixou a perder de vista o artista mais perfeito no gênero.
} 
Conseguiu imitar tão fielmente a letra de seu marido, que pôde escrever a si própria uma série de cartas assinadas com o nome de seu marido e contando as imputações mais injuriosas para ela.

Esta excelente mulher buscou em injúrias tão graves um dos principais motivos do seu pedido de separação.

O marido, porém, admirando a arte e o espírito com que a mulher o fez escrever, protesta com razão de sobra que aquelas cartas não são do seu punho.

O processo iniciado teve que ser suspenso e vários peritos parisienses estão atualmente curvados sobre as tais cartas, de lente em punho, procurando na letra ordinária da senhora a analogia com a outra letra, a fim de conhecerem a falsidade. Esta peça pregada a um pobre marido tem o seu quê de original.

("Malícia mulheril". O Globo, Rio de Janeiro, 7 de junho de 1876, p. 2).

Infelizmente, assim como os leitores do Globo, não temos notícias se a fraude foi comprovada pela justiça francesa. De qualquer forma, a malícia da esposa insatisfeita demonstrava como - até mesmo por subterfúgios - as mulheres encontravam meios de afirmar as próprias vontades. E se recapitularmos os exemplos que nos guiaram até aqui, perceberemos que esse último caso citado, não deve ser lido de maneira isolada.

\section{Conclusão:}

As notícias que vinham dos Estados Unidos e da Inglaterra revelavam um cotidiano de mulheres que impunham sua presença na esfera pública e faziam-se ouvidas nos meios institucionais. Lançando mão das considerações de Hannah Arendt (ARENDT, 2007 [1958]), a esfera pública revelava a pluralidade humana que antes se fazia homogênea nos espaços privados. Dessa maneira, era na rua que as mulheres tornavam-se perceptíveis aos outros, assim como era na rua que as mulheres afirmavam-se para si e em relação às suas semelhantes. Por isso, a invasão feminina do espaço público resultaria em trocas, identificações e solidariedades entre as próprias mulheres. Daí a formação de verdadeiros "contra poderes" capazes de questionar o status quo.

Conforme demonstrado, eram muitas as notícias que tocavam no tema do feminismo ao redor do mundo. As pautas se referiam às mulheres que lutavam por cidadania; por condições dignas de trabalho; pelo direito de desfazer laços que as submetiam. Dessa maneira, no Globo, eram apresentados contextos diversos, de mulheres que encontravam meios coletivos, ou individuais, de se expressarem nos meios institucionalizados pelo poder. Como sabemos, as brasileiras teriam acesso ao voto na década de 1930, sendo assim, acreditamos ser de grande valia reconhecermos que o tema da representatividade feminina já se fazia presente anteriormente, através das malhas do discurso midiático. 
Por fim, voltemos à pilhéria inicial: mas, as mulheres faziam as leis?

No início do item II deste artigo, intitulado Mas, até parece que as mulheres fazem as leis, citamos um pequeno texto enviado por um correspondente situado nos EUA, e que tocava na questão das liberdades desfrutadas pelas estadunidenses, que circulavam sós nos espaços públicos. Conforme dito, em determinado momento nosso redator, em tom de pilhéria, chega a cogitar que não seria absurdo cogitar mãos femininas empenhadas na redação das leis naquele país, haja vista a suposta benevolência com que as mulheres seriam tratadas.

De início, o mecanismo humorístico da frase se fazia compreensível pelo olhar estrangeiro do redator, completamente surpreso com a inserção social das mulheres norteamericanas. Por outro lado, não seria equivocado cogitar que o chiste era composto também pela expectativa em relação ao seu público-alvo: os leitores brasileiros do Globo.

Nesse sentido, tendo-se em vista a realidade patriarcal do contexto brasileiro de então, a hipótese de que as mulheres pudessem fazer as leis só poderia soar como piada suscetível de gargalhadas. Mas, neste caso, o "só" seria excessivamente peremptório. Entre tantas notícias que abordavam as mobilizações e as conquistas feministas ao redor do mundo, muitas leituras poderiam surgir e, talvez, as supostas gargalhadas previstas pudessem se converter em "sorrisos amarelos" nas faces de leitores e leitoras que, após tomarem contato com realidades tão diversas, poderiam questionar a própria realidade vivenciada.

Pensamos, então, que tal noticiário flertava com uma polissemia de sentidos que escapava às expectativas dos editores do periódico. Tantas abordagens sobre os caminhos percorridos por mulheres que, forçosamente, faziam-se ouvidas nos meios oficiais de poder, poderiam confluir para uma percepção entre os leitores e, principalmente, entre as leitoras brasileiras de então: sim, as mulheres faziam as leis.

\section{Notas}

\footnotetext{
${ }^{1} \mathrm{O}$ texto deste artigo integra a minha dissertação de mestrado em Teoria e História Literária, defendida no Instituto de Estudos da Linguagem da Universidade Estadual de Campinas em 2014. Ver: SALVAIA, Priscila. Diálogos possíveis: o folhetim Helena (1876), de Machado de Assis, no jornal O Globo. (Dissertação de Mestrado em Teoria e História Literária). Campinas: IEL/UNICAMP, 2014.

${ }^{2}$ Citamos aqui alguns dos trabalhos que nos orientam metodologicamente: CHALHOUB, Sidney. Machado de Assis, historiador. São Paulo: Companhia das Letras, 2003.; CHALHOUB, Sidney; NEVES, Margarida de
} 
Souza; PEREIRA, Leonardo Affonso de Miranda (orgs.). História em cousas miúdas: capítulos de história social da crônica no Brasil. Campinas-SP: Editora da UNICAMP, 2005.; CANO, Jefferson. "Mistérios do Rio de Janeiro: em torno das Memórias de um sargento de milícias e seu público." ANTÍTESES, v.6, n 11, p.53-75, jan./jun. 2013.

${ }^{3}$ Todas as referências ao jornal $O$ Globo foram retiradas diretamente do periódico, cujos números encontram-se disponíveis para consulta no site da Hemeroteca Digital Brasileira, através do seguinte endereço eletrônico: http://bndigital.bn.br/hemeroteca-digital/ [Acesso em 25 fev. 2016].

${ }^{4}$ Citando Robert Darnton: "Como é que normalmente entendemos as coisas? Acho que não é tirando insights do fundo da alma e projetando-os no meio que nos cerca, mas sim encaixando percepções em estruturas. Extraímos as estruturas de nossa cultura, pois a realidade, tal como a vivenciamos, é uma construção social. Nosso mundo é organizado - dividido em categorias, moldado pelas convenções e colorido por emoções comuns. Quando nos deparamos com algo significativo, tratamos de inseri-lo na ordem cognitiva que herdamos de nossa cultura; e em geral o verbalizamos. Assim, os significados, como a linguagem, são sociais, independente da inflexão que lhes demos. Ao inferir significados, dedicamo-nos a uma atividade profundamente social, sobretudo quando lemos." In: DARNTON, Robert. Os best-sellers proibidos da França pré-revolucionária. (Tradução: Hildegard Feist). São Paulo: Companhia das Letras, 1998, p.202.

${ }^{5}$ A fim de estabelecer algumas relações, vale dizer que, na época, um dos mais populares jornais do Rio de Janeiro, a Gazeta de Notícias, fundada em 1875, tinha seus exemplares vendidos avulsamente pelo preço de 40 réis (Ver: PEREIRA, Leonardo A. de Miranda. O Carnaval das Letras: literatura e folia no Rio de Janeiro do século XIX. ( $2^{\mathrm{a}}$ edição). Campinas-SP: Editora da Unicamp, 2004, p.54). Além disso, se nos referirmos às folhas consideradas mais onerosas e voltadas a públicos mais específicos, as comparações se tornam mais claras. Por exemplo, no caso da Semana Ilustrada, periódico semanal, ricamente ilustrado com modernas técnicas de xilogravura, os preços de assinatura em 1874 eram os seguintes: Corte (anual e semestral, respectivamente): $16 \$ 000$ e 9\$000/ Províncias (anual e semestral, respectivamente): $18 \$ 000$ e $11 \$ 000$. No caso do Jornal das Famílias, publicação feminina mensal, com dezenas de páginas, algumas delas coloridas, os preços de assinatura anual em 1874 eram os seguintes: Corte e Niterói: $10 \$ 000$ / Províncias: $12 \$ 000$. Por fim, a exposição de alguns dados financeiros da época, também pode nos ajudar a refletir sobre tais questões: em 1871, custava $10 \$ 000 \mathrm{o}$ aluguel de uma casa térrea no centro do Rio de Janeiro; em 1874, os ingressos para o teatro custavam de $2 \$ 000$ a $3 \$ 000$; em 1876, a renda de um advogado ou de um médico girava em torno de $2.000 \$ 000$, a de um professor em torno de $1.000 \$ 000$. Dados consultados no seguinte endereço eletrônico: http://www.unicamp.br/iel/memoria/base_temporal/Numeros/numeros.htm). [Acesso em 13 abr. 2016].

${ }^{6}$ Ver, por exemplo: GODINEAU, Dominique. "Filhas da liberdade e cidadãs revolucionárias." In: DUBY, Georges \& PERROT, Michelle (direção). História das Mulheres no Ocidente: o Século XIX. Volume 4. Porto: Afrontamento, 1991, p.21-39.

${ }^{7}$ Segundo Maria Zina Gonçalves de Abreu: "Nas nações católicas, poucas foram as mulheres que se juntaram a movimentos feministas, antes dos movimentos generalizados de emancipação da mulher da década de 1970 . O mesmo já não ocorreu nas nações que adotaram a Fé protestante. É verdade que as Igrejas Protestantes também preservaram a tradição patriarcal e que reduziram drasticamente as oportunidades de participação feminina na Igreja, com a eliminação do culto à Virgem e aos santos e o repúdio da vida em reclusão, em conventos e mosteiros. No entanto, a intensa prática religiosa doméstica, a leitura pessoal da Bíblia, a diferente leitura de algumas das doutrinas cristãs e as diferentes formas de disciplina eclesiástica abraçadas pelas diversas denominações protestantes criaram uma atmosfera mais propícia à rejeição das tradições culturais seculares que sublinhavam o estatuto de subordinação da mulher. A ênfase nas doutrinas da igualdade espiritual, na inviolabilidade da liberdade de consciência religiosa, e na responsabilidade de cada indivíduo pela sua própria salvação, estimulou o individualismo e a independência do pensamento, que levou as mulheres protestantes a cedo descobrirem a paradoxalidade do seu estatuto de subordinação social, e a começarem a questionar os papéis tradicionais que lhes eram socialmente impostos." In: ABREU, Zina. "Lutas das mulheres pelo direito de voto: movimentos sufragistas na Grã-Bretanha e nos Estados Unidos." Revista Arquipélago - História, $2^{\mathrm{a}}$ série, (volume VI), ano: 2002, p.443 - 469. Portugal: Universidade dos Açores.

${ }^{8}$ O programa de Naquet foi publicado no Le Temps, em 10 de setembro de 1875 . Sobre a questão do divórcio na França, ver: ROSIN, Francis. Les divorciaires: affrontments politiques et conceptions du mariage dans la France du XIXe. Siècle. Paris: Éditions Aubier, 1992. 


\footnotetext{
${ }^{9}$ Disponível no seguinte endereço eletrônico: http://www.assemblee-nationale.fr/evenements/code-civil-18041.asp [Acesso em 25 fev. 2016].
}

\section{Referências bibliográficas:}

ABREU, Zina. "Lutas das mulheres pelo direito de voto: movimentos sufragistas na GrãBretanha e nos Estados Unidos." Revista Arquipélago - História, $2^{\mathrm{a}}$ série, (volume VI), ano: 2002, p.443-469. Portugal: Universidade dos Açores.

ALMEIDA, Jane Soares de. "O movimento missionário e educacional protestante na segunda metade do século XIX: para cada igreja uma escola.” Educar, no 20, p.185-207, 2002. Curitiba-PR: Editora da Universidade Federal do Paraná (UFPR).

ARENDT, Hannah. A condição humana. Rio de Janeiro: Forense Universitária, 2007 [1958]. CANO, Jefferson. "Mistérios do Rio de Janeiro: em torno das Memórias de um sargento de milícias e seu público." ANTÍTESES, v.6, n 11, p.53-75, jan./jun. 2013.

CHALHOUB, Sidney. Machado de Assis, historiador. São Paulo: Companhia das Letras, 2003.

CHALHOUB, Sidney; NEVES, Margarida de Souza; PEREIRA, Leonardo Affonso de Miranda (org.). História em cousas miúdas: capítulos de história social da crônica no Brasil. Campinas-SP: Editora da UNICAMP, 2005.

DARNTON, Robert. Os best-sellers proibidos da França pré-revolucionária. (Tradução: Hildegard Feist). São Paulo: Companhia das Letras, 1998.

GARZONI, Lerice de Castro. Arena de combate: gênero e direitos na imprensa diária (Rio de Janeiro, início do século XX). (Tese de Doutorado em História). Campinas-SP: IFCH/UNICAMP, 2012.

GODINEAU, Dominique. "Filhas da liberdade e cidadãs revolucionárias." In: DUBY, Georges \& PERROT, Michelle (direção). História das Mulheres no Ocidente: o Século XIX. Volume 4. Porto: Afrontamento, 1991, p.21-39.

ISENBERG, Nancy. Sex and citizenship in Antebellum America. Chapel Hill: University of North Carolina Press, 1998.

KÄPPELI, Anne-Marie. "Cenas feministas". In: DUBY, Georges \& PERROT, Michelle (direção). História das Mulheres no Ocidente: o Século XIX. Volume 4. Porto: Afrontamento, 1991, p.541-579.

NEWMAN, Louise Michelle. White women's rights: the racial origins of feminism in the United States. Oxford: Oxford University Press, 1999.

PEREIRA, Leonardo A. de Miranda. O Carnaval das Letras: literatura e folia no Rio de Janeiro do século XIX. (2 edição). Campinas-SP: Editora da Unicamp, 2004.

PERROT, Michelle. "As mulheres e a cidadania na França: história de uma exclusão." In: As mulheres ou os silêncios da história. (Tradução: Viviane Ribeiro). Bauru-SP: EDUSC, 2005 [1998], p.327-341.

ROSIN, Francis. Les divorciaires: affrontments politiques et conceptions du mariage dans la France du XIXe. Siècle. Paris: Éditions Aubier, 1992.

SALVAIA, Priscila. Diálogos possíveis: o folhetim Helena (1876), de Machado de Assis, no jornal O Globo. (Dissertação de Mestrado em Teoria e História Literária). Campinas-SP: IEL/UNICAMP, 2014.

SCOTT, Joan W. and TILLY, Louise A. Women, work, and family. New York: Holt, Rinehart and Winston, 1989 [1978]. 
TEIXEIRA, Ivan. O Altar \& o Trono: Dinâmica do Poder em O Alienista. Cotia-SP: Ateliê; Campinas-SP: Editora da Unicamp, 2010.

VARIKAS, Eleni et RIOT-SARCEY, Michèlle. "Réflexions sur la notion d'exceptionnalité". Les Cahiers du GRIF, Paris, n. 37-38, 1998, p.77-89. 